\title{
Hybrid Public Offerings In China: The Case Of Class 'B' Shares
}

\author{
Vinay Datar, (Email: Vinay@ seattleu.edu), Seattle University \\ J. Fiona Robertson, (Email: Robertsf@seattleu.edu), Seattle University \\ David Mao, Seattle University
}

\begin{abstract}
When raising equity capital through the recently opened Shanghai stock exchange, Chinese companies can issue stock to Chinese nationals (' $A$ ' shares) or to non-Chinese nationals (' $B$ ' shares). Between 1990 and 199640 issuances of ' $B$ ' shares took place, often by firms that had previously issued 'A' shares. These class ' $B$ ' initial offerings are found to exhibit underpricing relative to first day trading prices, but to a much less severe degree than class ' $A$ ' share IPOs. Indeed, the extent of underpricing of class ' $B$ ' shares is found to be in line with underpricing in the U.S. This is surprising because for the most part these offerings are hybrids of IPOs and seasoned equity offerings, representing offerings of old (traded) claims in a new market setting. We examine a variety of standard explanations for underpricing of IPOs finding either no empirical support for the hypotheses, or that many of these explanations are not relevant to the characteristics of the Chinese market.
\end{abstract}

Two features of Chinese IPOs particularly seem to set them apart from new issues in the U.S. First, the capital market is not fully established, and second, the issuer of all IPOs is the government. The Chinese IPOs represent an attempt to transform a non-market economy, therefore, the prime objective may be the very creation of a viable market mechanism rather than a mere maximization of issue proceeds. We examine whether underpricing may be explained by this desire by the government (who also happens to be the issuer) to establish a market, and suggest a variety of lines for future research to cast further light on this hypothesis

\section{INTRODUCTION}

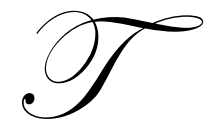

he emergence of stock markets in the People's Republic of China (PRC) in December 1990 allows a unique opportunity to examine the issuance of initial public offerings (IPOs). It is widely established, in the context of a variety of international stock markets, that IPOs are broadly underpriced in the sense that the average issue price is below the average after-market price. ${ }^{1}$ IPO underpricing has also been found in China with regard to the issuance of a class of shares issued only to Chinese nationals (known as Class 'A' shares) by Datar and Mao $(1997)^{2}$. In this paper we examine the pricing of a companion set of shares, class 'B' shares, which have in common almost all of the attributes of class 'A' shares, except that class 'B' shares are available only to non-Chinese nationals. What makes these shares particularly intriguing is that a number of them are issued after the issuance of class ' $A$ ' shares, so that these class ' $B$ ' shares have a flavor of both an IPO and of a seasoned equity issue. Class 'B' shares offer essentially all the same rights as class ' $A$ ' shares, hence the existence of seasoned class ' $A$ ' shares would seem to provide a publicly available benchmark price. Despite this we find evidence of consistent underpricing of class ' $\mathrm{B}$ ' shares. The degree of underpricing for class ' $\mathrm{B}$ ' shares is comparable to that found in the US and other well developed stock markets for IPOs. The level is surprisingly high, particularly for those B shares that can be considered a seasoned offering. We examine a variety of possible reasons for this underpricing, finding that for the most part explanations developed to explain IPO underpricing in the US are either irrelevant or lack empirical support in the Chinese context. We offer, as a possible explanation for the underpricing in the Chinese context, the hypothesis that the goal of the government in setting IPO prices is not necessarily revenue maximization, but rather that the 
government is concerned with the creation of a viable market mechanism. Underpricing may be a reputation building device, with IPO prices to foreigners set at a level that allows them to earn returns on Chinese IPOs similar to those that they can expect to earn by investing in IPOs on other financial markets. Essentially the Chinese government may be acting as a price taker in the international IPO market.

The remainder of this study proceeds as follows: Section 2 describes the institutional setting, the sources of data and provides descriptive statics for Chinese IPOs; Section 3 provides empirical analysis of a variety of theories to explain IPO underpricing; and Section 4 concludes with a summary of our findings and suggestions for further research in this area.

\section{IPOS IN THE CHINESE CONTEXT}

\section{Data and Market Characteristics}

Many aspects of Chinese IPOs are unique to this market. In China, both the firm and the underwriter are related to the government. Four types of buyer are distinguished: 1) State shareholders, 2) Legal person shareholders, 3) Individual shareholders (domestic), and 4) Foreign shareholders. Only Chinese nationals can hold 'A' shares (and nationals are not allowed to buy non-A shares). 'A' shares are tradable in China in RMB denomination. ' $\mathrm{B}$ ' shares trade in China in dollar denominations, and ownership is restricted to foreign investors. 'A' and 'B' shares are at par with regard to voting rights and liquidation rights. ' $\mathrm{C}$ ' shares are held by State and legal person shareholders, which are both government owned entities (the distinction between them is not well defined and remains ambiguous). Some additional shares are traded in Hong Kong ('H' shares) and in New York ('N' shares).

Between December 1990 and June 1996, approximately 226 A share issues were listed on the Shanghai Stock Exchange. Of these, 32 of the corporations also subsequently issued B shares. In addition, 8 corporations issued no A shares but did issue B shares. All issues involved the sale of $\mathrm{C}$ shares, sold only to government agencies. We do not concern ourselves with $\mathrm{C}$ shares here, focusing on publicly issued shares.

The data on these IPOs was gathered from the Shanghai Securities Newspaper. In addition to the offer price, the newspaper provides data on both the open price and the close price on the first day of trading. This allows us to examine the underpricing, aftermarket return on the first trading day and the volatility on the first trading day.

\section{Descriptive Statistics}

Table 1 shows the descriptive statistics of the class 'B' IPOs (and some characteristics of all Chinese IPO's for comparison). In terms of offer size and market price, Chinese IPOs are similar to U.S. IPOs. In looking at class 'A' shares, converted to common currency, the median offer price of RMB 4.8 is twenty-one times smaller than the median price of $\$ 12$ in the U.S. (all comparisons are based on the official exchange rate of 8.5RMB/U.S. dollar).

Looking at class ' $\mathrm{B}$ ' issues, firms issuing type ' $\mathrm{B}$ ' shares are, on average, about twice the size of those issuing only 'A' shares whether measured by market value (661m RMB against 363m RMB) or by total assets (232m RMB versus $92 \mathrm{~m} \mathrm{RMB}$ ). The typical offer size is twice that for ' $A$ ' shares, so that there is a tendency for only the largest Chinese firm's to offer shares to non-nationals. The median offer price of $\$ 0.40$ per share for ' $\mathrm{B}$ ' shares is similar to that for 'A' shares (for which the median offer price is $\$ 0.56$ ), but is only one thirtieth the typical U.S. offer price of $\$ 12$. The number of shares offered for ' $\mathrm{B}$ ' offerings is about sixty times higher for Chinese offerings compared to US offerings (62 million vs. 1.1 million in the U.S. as reported by Booth and Chua, 1996). Thus these observations suggest that, in China, for both ' $\mathrm{A}$ ' and ' $\mathrm{B}$ ' shares, the same size 'pie' is sliced into very small pieces. In the context of class ' $\mathrm{A}$ ' shares, this may be rationalized by the desire to make shares available to a widespread clientele. However given that most ' $\mathrm{B}$ ' shares are bought by corporations or other institutions, the need for such small denomination issuance is less clear here. A natural explanation for this might seem to be that the issuer wishes to ensure a similar "price per vote" for the ' $\mathrm{B}$ ' shares to that paid by ' $\mathrm{A}$ ' shareholders, since ' $\mathrm{A}$ ' and ' $\mathrm{B}$ ' shares offer the same rights to their holders. However, recall that eight of the forty issues are for firms that do not have existing ' $A$ ' shares 
outstanding, and there is no difference in the offering prices on these shares from those firms that have 'A' shares outstanding. Even for these truly unseasoned ' $\mathrm{B}$ ' issues, offer prices are still orders of magnitude smaller than for U.S. new issues.

Table 1: Descriptive Statistics

\begin{tabular}{|l|c|c|c|c|c|}
\hline & Mean & Median & Range & 25th percentile & 75th percentile \\
\hline Firm Characteristics & & & & & \\
\hline Market Value of Firm, RMB & & & & \\
\hline Total Assets, RMB & $1058.7 \mathrm{mil}$ & $661.113 \mathrm{mi}$ & $222.08 \mathrm{~m}-4.5394 \mathrm{bil}$ & $426.944 \mathrm{mil}$ & $1249.10 \mathrm{mil}$ \\
\hline Growth Options & $262.7 \mathrm{mil}$ & $232.0 \mathrm{~m}$ & $64 \mathrm{mil}-831.8 \mathrm{mil}$ & $142.964 \mathrm{mil}$ & $332.533 \mathrm{mil}$ \\
\hline Number of outstanding Shares & 3.7 & 3.5 & 1.5 to 7.3 & 2.89 & 4.135 \\
\hline Issue Characteristics & $204.3 \mathrm{mil}$ & $187.6 \mathrm{mi}$ & $3 \mathrm{mil}$ to $733 \mathrm{mil}$ & $92.2942 \mathrm{mil}$ & $289.283 \mathrm{mil}$ \\
\hline Offer size, $\$$ & & & & & \\
\hline Offer Price, $\$$ & $40.3 \mathrm{mil}$ & $24.4 \mathrm{mil}$ & $11.3 \mathrm{~m}$ to 191.6 & 17.48 & 41.377 \\
\hline Number of shares offered (mil) & 3.49 & 0.403 & 0.185 to 70.9 & 0.34325 & 0.735 \\
\hline Retained Ownership, $\%$ & 62.2 & 65 & 1 to 200 & 31.5 & 95 \\
\hline Trading Characteristics & 60.5 & 62.2 & 41.1 to 89.9 & 52.3201 & 67.5521 \\
\hline Returns on 1st trading day, $\mathrm{R}_{1}$ & & & & & \\
\hline Volatility on the first trading day, $\sigma$ & 9.83 & 0.57 & -17.76 to 52.31 & -2.6273 & 9.18597 \\
\hline Underpricing, UND & 18.99 & 10.21 & -18.45 to 87.5 & 0.8832 & 27.3009 \\
\hline
\end{tabular}

We turn next to an examination of the trading characteristics of the share offerings under study.

We define returns on the first trading day as:

$\mathrm{R}_{1}=(($ closing price on first trading day/opening price $)-1) * 100$.

The mean return on first day trading in ' $\mathrm{B}$ ' shares is almost $5 \%$ (with a t-statistic of 2.06). In contrast the median first day return of $0.6 \%$ is not statistically significant (with a p-value of only 0.3$)^{3}$. The positive expected returns on first day trading in ' $\mathrm{B}$ ' shares is in contrast to the returns on first day trading in ' $\mathrm{A}$ ' shares, which were zero. The after-market appears to be efficient in China for ' $\mathrm{A}$ ' shares, but not for ' $\mathrm{B}$ ' shares ${ }^{4}$. Buyers in the after-market for ' $\mathrm{B}$ ' shares appear to have profit opportunities on average. This is rather disturbing (particularly in light of the efficiency of the aftermarket for 'A' shares) since one would think that the traders in 'B' shares are sophisticated investors. Because first day prices are not a random walk, in investigating underpricing of new issues, we need to consider whether we should compare the issue price with the opening or the closing price. Since prices are not a random walk on the first day of trading, we consider two alternative measures of underpricing, based on either the opening or the closing price.

We define underpricing as either:

$\mathrm{UND}=(($ Closing price on first trading day/Offer Price $)-1) * 100$ or

$\mathrm{UND}_{1}=(($ Opening price on first trading day/Offer Price $)-1) * 100$

\footnotetext{
${ }^{*}$ The exchange rate has been officially managed at approximately 8.5 RMB/ U.S. \$
} 
The diagram below clarifies these definitions.

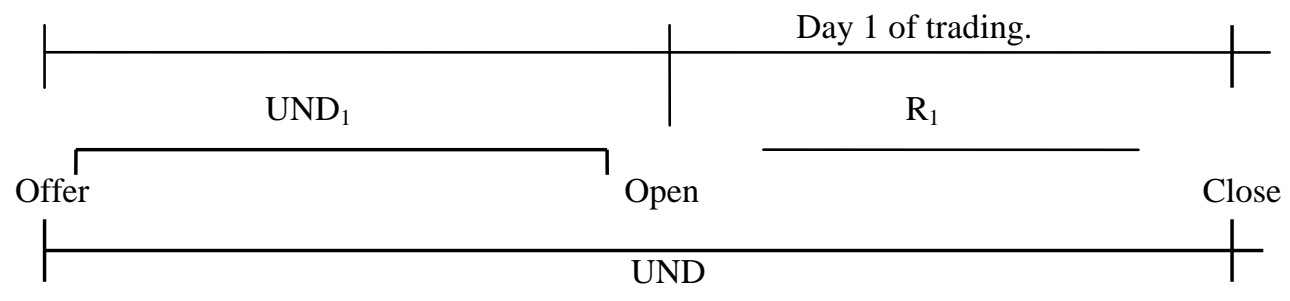

We further define the volatility of returns on the first trading day as the absolute value of returns on the first trading day; i.e.: $\sigma=\left|R_{1}\right|{ }^{5}$

The volatility on the first trading day is much higher for class ' $\mathrm{B}$ ' shares than has been found in studies of U.S. IPOs, and comparable to the volatility previously found for class ' $\mathrm{A}$ ' shares $(9.7 \%$ for class ' $\mathrm{B}$ ' shares in China, 9.3\% for class 'A' shares in China, vs. 5.6\% in the U.S. as reported by Barry and Jennings (1993) ${ }^{6}$. This suggests a higher level of ex-ante uncertainty about the post-offer price compared to the U.S. While this result was not surprising for class ' $A$ ' share offerings for an emerging market, given that for 32 of the 'B' offerings, a market previously existed in ' $A$ ' shares, this high degree of volatility is surprising for ' $B$ ' shares. We further investigated whether there was any difference between the volatility of first day trading prices for those class ' $B$ ' shares that had previously issued ' $A$ ' shares, and those that had not. Surprisingly, volatility was higher for those issues with 'A' shares already outstanding $(\sigma=10.15 \%)$ compared to those with no 'A' shares outstanding $(\sigma=4.03 \%)$. This does not seem to fit with the idea that a good deal of first day volatility is due to uncertainty about the market valuation of the issue, since in that case we would expect the existence of outstanding ' $A$ ' shares to reduce first day uncertainty for ' $B$ ' shares.

\section{Section Summary}

- $\quad$ The median offer size in China for 'A' shares is similar to U.S. IPOs; however, for 'B' share issues, these firms are twice the size of a typical Chinese (or U.S.) IPO.

- $\quad$ The median offer price of Chinese class 'B' issuances is thirty times smaller than the median offer price of U.S. IPOs.

- $\quad$ Positive profits are available by buying at the opening price in the aftermarket, on average.

- Aftermarket prices display a high degree of volatility, even when trading in 'A' shares predates the issuance of 'B' shares.

\section{Empirical Results}

As reported in Table 2, average underpricing in China is about 18\%, when compared to closing prices, or $14 \%$ when compared to opening prices. This is comparable in magnitude to the degree of underpricing found in U.S. studies. $^{7}$ A striking fact is the fact that there is only a single one of the 40 issues that exhibits any degree of overpricing (when compared to opening prices; 4 issues show overpricing relative to closing prices) and only 6 that show essentially zero (less than 1\%) returns. The motivation for this consistent degree of underpricing in China is puzzling at first glance. It appears that buyers of class 'B' IPOs are essentially being guaranteed a profit on their purchases.

To explore this issue, we examine some of the explanations developed in the U.S. context to explain IPO underpricing. Ibbotson (1975) and Tinic (1988) suggest that firms underprice IPOs to reduce their vulnerability to potentially costly lawsuits. Rock (1986) and Beatty and Ritter (1986) propose that underpricing is required to prevent adverse selection against uninformed traders (a type of winner's curse phenomenon). Allen and Faulhaber (1989), 
Grinblatt and Hwang (1989), and Welch (1989) propose that firms use underpricing as a signal of quality and derive benefits of a better price in subsequent offerings. Rudd (1993) argues that the observed underpricing is merely an artifact of the aftermarket support provided by the underwriter. Finally recent work suggests that firms use underpricing to achieve a broad ownership distribution thereby increasing liquidity [Booth and Chua (1996)] and diffusion of control [Brennen and Franks (1995)].

Table 2: Distributional Characteristics of Underpricing

Underpricing is measured as percentage returns from the offer price to the closing price on the first trading day.

\begin{tabular}{|l|c|}
\hline Equally Weighted Mean & 18.99 \\
\hline t-statistic $\left(\mathrm{H}_{0}=\right.$ mean returns are zero $)$ & 4.77 \\
\hline \# of observations & 40 \\
\hline \# of observations with positive returns & 36 \\
\hline \# of observations with negative returns & 4 \\
\hline Skewness & 1.122 \\
\hline Kurtosis & 0.73186 \\
\hline Mean Return weighted by offer size & 16.62 \\
\hline t-statistic $\left(\mathrm{H}_{0}=\right.$ mean returns are zero $)$ & 4.05 \\
\hline
\end{tabular}

\section{Hot and Cold Markets}

Ibbotson and Jaffe (1975) find that the degree of underpricing is cyclical and concentrated in particular periods ('Hot' periods). Ritter (1984) finds that in the 1980s, the hot issue market is almost exclusively associated with natural resource issues. In light of these findings, we investigate whether there are either time or industry effects present in our data.

As is apparent from table 3, the degree of underpricing shows signs of decline over time (this conclusion is subject to the limitations of the small number of offerings year by year). Looking beyond the annual averages, we find that from December 1994 to the last issue of our sample (in June of 1996) no issue was underpriced by as much as 5\%, and from February of 1994 to the end of the sample 13 of the 16 issues were underpriced by less than 6\%. Thus almost all of the significantly underpriced issues occurred in the first four years of the operation of the Shanghai stock market. To the extent that any hot market existed in China, it appears to have been associated with the earliest IPOs.

As to whether there is any evidence of an industry effect, the only discernible difference is the small degree of underpricing associated with the three utility issues out of the forty ${ }^{8}$.

The fact that the degree of underpricing shows signs of decline over time may be consistent with the view that the issuer's motive is to create a viable trading mechanism rather than maximizing the issue proceeds, since in this case the early issues are critical to establishing the credibility of the market. Over time, the need to offer the prospect of excess first day profits as an inducement to enter the market may decline (however, it should be noted that Datar and Mao (1997) found no decline in underpricing over time for the A stocks - whether this could be due to differences in the attitudes of domestic and foreign investors can only be speculated upon).

\section{Information Signaling}

Signalling models ${ }^{9}$ imply that higher underpricing is associated with increased likelihood of subsequent offering and also that underpricing is inversely related to the degree of retained ownership. We find no evidence in our data of the negative cross-sectional relationship between retained ownership and underpricing (see Table 4 column 8 and Table 5 equation 4) implied by signaling models. 
Table 3

Underpricing is measured as percentage returns from the offer price to the closing price on the first trading day.

(Panel 'A')": Underpricing By Year Of Issuance

\begin{tabular}{|c|c|c|c|c|c|c|}
\hline \multicolumn{2}{|c|}{} & \multicolumn{5}{|c|}{ Underpricing, UND\% } \\
\hline Year of IPO & Number of IPOs & Mean (t value) & Median & Range & $\begin{array}{c}\mathbf{2 5}^{\text {th }} \\
\text { percentile }\end{array}$ & $\mathbf{7 5}^{\text {th }}$ percentile \\
\hline 1992 & 9 & $7.91 \%(2.14)$ & $6.75 \%$ & $-9.19 \%$ to $24.88 \%$ & $0.95 \%$ & $13.06 \%$ \\
\hline 1993 & 13 & $34.94 \%(5.23)$ & $29.03 \%$ & $0 \%$ to $87.5 \%$ & $19.19 \%$ & $52.58 \%$ \\
\hline 1994 & 12 & $19.38 \%(2.21)$ & $4.38 \%$ & $-18.45 \%$ to $80 \%$ & $0.25 \%$ & $41.69 \%$ \\
\hline 1995 & 2 & $-4.04 \%(-0.79)$ & $-4.04 \%$ & $-9.17 \%$ to $1.08 \%$ & $-9.17 \%$ & $1.08 \%$ \\
\hline Jan-June1996 & 4 & $2.43 \%(2.37)$ & $2.43 \%$ & $0 \%$ to $4.86 \%$ & $0.90 \%$ & $3.96 \%$ \\
\hline Total & 40 & $18.99 \%(4.77)$ & 10.21 & $-18.45 \%$ to $87.5 \%$ & $0.88 \%$ & $27.3 \%$ \\
\hline
\end{tabular}

(Panel 'B'): Underpricing By Industry

\begin{tabular}{|c|c|c|c|c|c|c|}
\hline & \multicolumn{5}{|c|}{ Underpricing, UND\% } \\
\hline $\begin{array}{c}\text { Business } \\
\text { Segment }\end{array}$ & Number of IPOs & Mean (t value) & Median & Range & $\mathbf{2 5}^{\text {th }}$ percentile & $\mathbf{7 5}^{\text {th }}$ percentile \\
\hline Commercial & 3 & $30.41 \%(1.17)$ & $18.67 \%$ & $-7.43 \%$ to $80 \%$ & $-7.43 \%$ & $80 \%$ \\
\hline Industrial & 28 & $19.54 \%(3.94)$ & $9.90 \%$ & $-18.45 \%$ to $87.5 \%$ & $0.65 \%$ & $32.45 \%$ \\
\hline Misc. & 3 & $22.28 \%(2.11)$ & $24.29 \%$ & $3.1 \%$ to $39.44 \%$ & $3.1 \%$ & $39.44 \%$ \\
\hline Property & 3 & $14.08 \%(1.98)$ & $19.19 \%$ & $0 \%$ to $23.05 \%$ & $0 \%$ & $23.05 \%$ \\
\hline Utilities & 3 & $4.07 \%(2.42)$ & $3.05 \%$ & $1.81 \%$ to $7.36 \%$ & $1.81 \%$ & $7.36 \%$ \\
\hline Total & 40 & $18.99(4.77)$ & $10.21 \%$ & -18.45 to $87.5 \%$ & $0.88 \%$ & $27.3 \%$ \\
\hline
\end{tabular}

In China, the signaling motivation may have only a limited relevance to the extent that a single issuer (government) is issuing all the IPOs, and in this context there is no need to use a signal to separate from other issuers. ${ }^{10}$ However, one may wish to take a broader view of signaling theories that the issuer wishes to 'leave a good taste in the investor's mouths' so that future offerings from the same issuer will be well received. To this extent underpricing may be an essential 'signal', or a reputation building device on the part of the Chinese government, knowing that subsequent offerings are to be made. Perotti (1995) has modeled this phenomenon. Our evidence of declining underpricing over time could be viewed as supportive of this view if the early issues are viewed as being sufficiently numerous to establish a reputation.

\section{Ex-Ante Uncertainty}

According to the winner's curse hypothesis, uninformed investors face adverse selection in that they get a larger allocation of overpriced issues. Underpricing is essential to provide a fair return to the uninformed investors in the presence of this adverse selection. At the same time, the issuer wants to maximize issue proceeds by minimizing underpricing. Therefore in equilibrium the level of underpricing increases with ex-ante uncertainty about firm value. ${ }^{11}$

The potential for a winner's curse is likely to play a much stronger role in Chinese IPOs than in U.S. IPOs due to the existence of a single issuer in China. For example, individual firms in the U.S. do not have an incentive to underprice as long as there is aggregate underpricing. But, in the Chinese context, the issuer (the government) has a strong incentive to create a viable market by underpricing because the same issuer will be in the market with several more IPOs. Furthermore, the prime objective of the government may be the very creation of a viable market mechanism rather than maximizing issue proceeds; i.e. the considerations of wide dispersion may dominate any desires to minimize underpricing. Consistent with this view, in our sample almost every IPO was underpriced. 
Table 4: Underpricing In Portfolios

The Sample consists of all B stocks listed on the Shanghai Stock Exchange, from inauguration in 1990 to June 1996 . The sample has 40 listings/IPOs of class 'B' shares. The sample is broken down into sets of 5 (quintile) portfolios based on various sorting variables (explanatory variables). Market Value is the number of shares outstanding times the offer price. Total Assets is book value of firm's assets. Growth options is a ratio of first opening price divided by the book value per share. Offer Size is the natural log of number of shares offered times the offer price. Retained Ownership is the percentage of listed firm that is retained by the issuer. Aftermarket Volatility $(\sigma)$ is the absolute value of percentage returns on the 1 st trading day. Aftermarket returns $\left(R_{1}\right)$ are measured as percentage returns realized from open to close on the first trading day. Underpricing is measured as percentage returns from the offer price to the closing price on the first trading day. Equally weighted values of underpricing are reported below for the quintile portfolios.

\begin{tabular}{|c|c|c|c|c|c|c|c|c|c|c|}
\hline \multicolumn{11}{|c|}{ Underpricing, UND\% (By Quintiles Of Explanatory Variables) } \\
\hline 泀 & 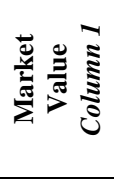 & 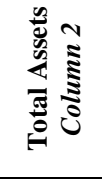 & ن⿺辶卂 & 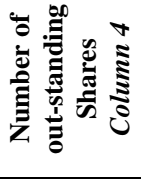 & 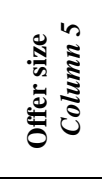 & 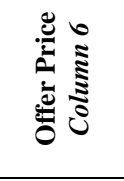 & 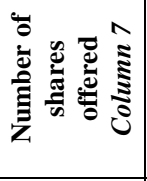 & 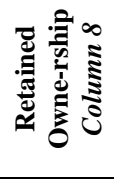 & 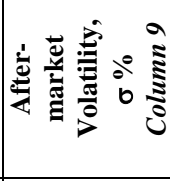 & 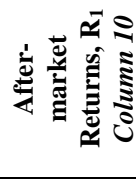 \\
\hline 1 (Lowest) & $27.87 \%$ & $27.68 \%$ & $0.24 \%$ & $8.87 \%$ & $18.07 \%$ & $0.24 \%$ & $8.87 \%$ & $22.17 \%$ & $6.12 \% \$$ & $3.35 \% \$$ \\
\hline 2 & $7.47 \%$ & $16.08 \%$ & $22.53 \%$ & $35.58 \%$ & $18.75 \%$ & $22.74 \%$ & $32.22 \%$ & $20.92 \%$ & $5.38 \% \$$ & $1.47 \% \$$ \\
\hline 3 & $19.88 \%$ & $11.35 \%$ & $30.63 \%$ & $17.37 \%$ & $21.37 \%$ & $35.41 \% *$ & $26.45 \%$ & $17.96 \%$ & $19.62 \% \$$ & $7.89 \% \$$ \\
\hline 4 & $17.42 \%$ & $13.13 \%$ & $18.28 \%$ & $7.37 \%$ & $11.41 \%$ & $26.91 \% \$$ & $1.39 \%$ & $25.35 \%$ & $14.61 \% \$$ & $27.65 \% \$$ \\
\hline 5 (Highest) & $157 \%$ & $26.70 \%$ & $23.27 \%$ & $25.75 \%$ & $25.34 \%$ & $8.05 \%$ & $24.18 \% \$$ & $8.55 \%$ & $49.21 \%$ & $52.99 \%$ \\
\hline $\mathrm{R}^{2}$ & $7.3 \%$ & $7.63 \%$ & $16.7 \%$ & $18.12 \%$ & $3.4 \%$ & $27.4 \%$ & $19.9 \%$ & $5.3 \%$ & $41.5 \%$ & $60 \%$ \\
\hline
\end{tabular}

*denotes significantly different from the highest quintile at the $5 \%$ level.

\$denotes significantly different from the highest quintile at the $10 \%$ level.

In Table 5, we report results of regressing underpricing on several standard proxies for ex-ante uncertainty such as offer size, firm size, aftermarket volatility and growth options. Table 4 reports the degree of underpricing for the same variables ranked into quintiles for evidence of more general correlations. The evidence is mixed. Equation 3 of table 5, and column 9 of table 4, both show that aftermarket uncertainty plays a role in explaining returns (this is still true, though less so if we use $\sigma_{1}$ as our measure of aftermarket volatility ${ }^{12}$ ). None of the other proxies for uncertainty show any relationship to underpricing.

Hence, we have some limited evidence suggesting that ex-ante uncertainty does help to explain both the variation in underpricing and the level of underpricing (the intercept is only about 5\%). However this evidence does not survive further scrutiny. In particular, in this case it may be more appropriate to consider the relationship between $\mathrm{UND}_{1}$ and volatility. Recall that UND measures underpricing relative to the closing price. Since our measure of volatility is the absolute value of first-day returns and on average, first day returns are positive, we have an overlap in the time periods for measuring volatility and aftermarket returns that virtually ensures a positive relationship between these variables. Using $\mathrm{UND}_{1}$ (underpricing relative to opening price) the coefficient on $\sigma$ falls to 0.36 ( $\mathrm{t}$ value of 1.99) and an $\mathrm{R}^{2}$ of $9.4 \%$. Hence, once we eliminate the overlap in time periods, the impact of aftermarket volatility becomes considerably less significant. Once again, we have to recall that for many of these issues, existing ' $\mathrm{A}$ ' share prices are available which one might expect would alleviate the adverse selection problem. We are left to conclude that this data seems to be consistent with the notion that the issuer is concerned about the potential failure of an issue (due to uncertainty and adverse selection) but not particularly concerned about maximizing issue proceeds (or minimizing underpricing) and therefore selects a high level of average underpricing and this is consistent with finding no relationship between underpricing and uncertainty. 
Table 5: What's Driving The Underpricing?: Regression Evidence

The Sample consists of all class 'B' stocks (40 listings) listed on the Shanghai Stock Exchange, from inauguration in 1990 to June 1996. LOSZ is the natural $\log$ of number of shares offered times the offering price. LMVAL is the natural log of number of shares outstanding times the offering price. Aftermarket Volatility $(\sigma)$ is the absolute value of percentage returns on the 1st trading day. Retained Ownership is the percentage of listed firm that is retained by the issuer. 'Growth options' is a ratio of first opening price divided by the book value per share. Aftermarket returns on the 1st day $\left(\mathrm{R}_{1}\right)$ are measured as percentage returns realized from open to close on the first trading day. LPRC is the log of offer price. In equations $1-8$, the dependent variable is underpricing, this is measured as percentage returns realized from offer to close on the first trading day. In equation 9 the dependent variable in uderpricing measured as percentage returns from offer to open on the first trading day (t-statistics are in parentheses).

\begin{tabular}{|c|c|c|c|c|c|c|c|c|}
\hline 華 & 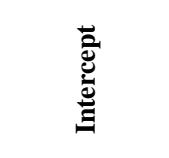 & 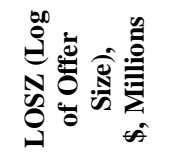 & 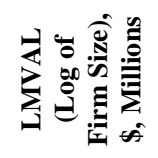 & 尝 & 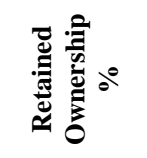 & 气气 & 总 & 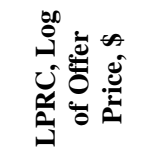 \\
\hline 1 & $21.75(19.78)$ & $\begin{array}{c}-0.814(-0.14) \\
\mathrm{R}^{2}=.05 \%\end{array}$ & & & & & & \\
\hline 2 & $15.45(35.03)$ & & $\begin{array}{c}0.527(0.10) \\
\mathrm{R}^{2}=0.03 \%\end{array}$ & & & & & \\
\hline 3 & $4.285(3.55)$ & & & $\begin{array}{l}1.52(6.6) \\
\mathrm{R}^{2}=53.3 \% \\
\end{array}$ & & & & \\
\hline 4 & $30.49(25.11)$ & & & & $\begin{array}{l}-0.19(-0.4) \\
\mathrm{R}^{2}=0.56 \%\end{array}$ & & & \\
\hline 5 & $6.47(11.73)$ & & & & & $\begin{array}{l}3.4(1.13) \\
\mathrm{R}^{2}=3.3 \% \\
\end{array}$ & & \\
\hline 6 & $12.15(2.36)$ & & & & & & $\begin{array}{c}1.41(9.2) \\
\mathrm{R}^{2}=69.23 \%\end{array}$ & \\
\hline 7 & $\begin{array}{l}18.46 \\
(4.08)\end{array}$ & & & & & & & $\begin{array}{l}-1.98(-0.7) \\
\mathrm{R}^{2}=1.26 \%\end{array}$ \\
\hline 8 & $\begin{array}{c}15.03 \\
(22.18) \\
\end{array}$ & $\begin{array}{c}0.99 \\
(6.33) \\
\end{array}$ & & & & & & $\begin{array}{l}-2.19(-0.69) \\
\mathrm{R}^{2}=1.3 \% \\
\end{array}$ \\
\hline \multicolumn{9}{|c|}{ Dependent variable in equation 9 is $U N D_{I}$} \\
\hline 9 & & & & $\begin{array}{l}0.36(1.99) \\
\mathrm{R}^{2}=9.4 \%\end{array}$ & & & & \\
\hline
\end{tabular}

\section{Other Explanations}

Given that the issuer of all these IPOs is the government, lawsuit avoidance is unlikely to be a motivation for underpricing. Control aspects are very unlikely to play a meaningful role in underpricing (and associated broad dispersion) because the government owns at least $50 \%$ of the shares in most IPOs. Aftermarket price support is non-existent and therefore has no role in observed underpricing. As noted above, traditional signaling considerations are moot because a single issuer (government) offers all the IPOs.

We propose that the Chinese IPOs are underpriced primarily to promote a viable capital market (rather than to maximize individual issue proceeds). The lack of support for alternative explanations of IPO underpricing and the evidence on the uniformity of underpricing is consistent with this proposition, as is, possibly, the concentration of severely underpriced issues in the early years of the stock market.

\section{SECTION SUMMARY}

- $\quad$ The level of IPO underpricing is comparable in size to U.S. IPOs. Furthermore, almost every issue is underpriced. There appears to be some tendency for underpricing to have fallen over time.

- $\quad$ There is no evidence of signaling; a) the incidence of subsequent issues is unrelated to the level of prior underpricing, b) the degree of retained ownership has no impact on the level of underpricing.

- Ex-ante uncertainty has very marginal impact on the variation in underpricing and on the level of underpricing. 
- $\quad$ The issuer has a preference for a small offer price regardless of the offer size, suggesting that the issuer wants to make the issues affordable to a broad clientele, at least domestically.

Overall, the evidence suggests that the issuer deliberately underpriced the issues to achieve acceptance of these new issues, while possibly sacrificing issue proceeds in the interest of establishing the market.

\section{SUMMARY AND UNANSWERED QUESTIONS}

This study examines IPOs of ' $\mathrm{B}$ ' shares listed on the Shanghai stock exchange sold to non-Chinese nationals as of June 1996, representing 40 IPOs. For an emerging market, these issues are not economically insignificant; in fact a typical issue is larger than the average U.S. IPO in terms of both offer size and firm size.

We find that the mean underpricing is comparable to that observed in the U.S. (18\% in China vs. $16.4 \%$ in the U.S.). Furthermore, almost every issue is underpriced (as against just the average issue being underpriced), although there is evidence that the degree of underpricing is declining over time. Looking at the aftermarket, the market appears to be inefficient in the sense that on average the first aftermarket price does provide a profit opportunity.

Most explanations of underpricing in the U.S. context rely on the issuer's desire to maximize issue proceeds in the presence of the adverse selection faced by investors. This view does not fully explain the nature and extent of underpricing in Chinese data. We suggest that the Chinese government has deliberately underpriced IPOs in order to create a viable capital market; i.e. dispersion motives dominate any desires to minimize underpricing.

What makes these share issues of particular interest is the existence of class 'A' shares issued to Chinese citizens, giving the class ' $\mathrm{B}$ ' issue the flavor of both an IPO and a seasoned issue. The existence of underpricing for the class ' $\mathrm{B}$ ' issues is particularly surprising given the existence of currently trading class ' $\mathrm{A}$ ' shares. At least three erroneous issues should be dismissed in examining the difference in the pricing of $\mathrm{A}$ and $\mathrm{B}$ shares.

- $\quad$ Arbitrage discipline is limited due to restrictions on ownership of the shares. This argument lacks validity since the existence of many Chinese nationals in Hong Kong means that the strict division of ownership between A and B shares is in fact far from clear cut.

- $\quad$ B shares bear additional currency risk. This statement is not correct since B shares are priced in dollars, so there is no additional currency risk for foreign holders of these shares.

- Chinese shares bear unusual risks and this explains the underpricing. This notion is clearly incorrect. While it may be true that Chinese shares bear unusual risks, there is no reason why these risks should be associated particularly with the day of issue. It may well be that these shares will offer higher returns over time as compensation for the risk associated with the unstable situation in China, but there is no reason why initial buyers in particular are bearing any special risk.

Clearly study of these share issues has the potential to produce a number of novel insights into the operation of share markets in developing and transforming economies. A number of issues that bear further analysis if the appropriate information can be gathered could cast further light on our findings. In particular it would be desirable to know:

- Do 'A' and 'B' shares trade at par over time (appropriately adjusted for exchange rates, which may not be trivial issue given the existence of an official and an unofficial exchange rate for RMB)

- What is the price of 'A' shares in the companies that issue ' $B$ ' shares on the days around the new issues of ' $B$ ' shares?

- What happens to the prices of ' $\mathrm{B}$ ' shares over time? Given that prices are not a random walk on the first trading day, it would be of interest to know if either the opening or closing prices are efficient estimates of future prices. 
David Mao hand collected the data while working with Herbert Smith law offices, in Hong Kong. We thank faculty members at Seattle University for valuable comments. All errors are our own.

\section{REFERENCES}

1. Allen, Franklin and Gerald Faulhaber, 1989. Signaling by underpricing in the IPO market, Journal of Financial Economics, 23, 303-323.

2. Barry, Christopher and Robert Jennings, 1993. The opening price performance of initial public offerings of common stock, Financial Management 22 (1), 54-63.

3. Beatty, Randolph and Jay Ritter, 1986. Investment banking, reputation, and the underpricing of initial public offerings, Journal of Financial Economics, 15, 213-232.

4. Benveniste, Lawrence and Paul Spindt, 1989. How investment bankers determine the offer price and allocation of new issues, Journal of Financial Economics 24 (2), 343-362.

5. _ _ _ and William Wilhelm, 1990. A comparative analysis of IPO proceeds under alternative regulatory environments, Journal of Financial Economics 28, 173-208.

6. _ Walid Busaba, and William Wilhelm, 1996. Price stabilization as a bonding mechanism in new equity issues 42 (2), 223-255.

7. Booth, James and Lena Chua, 1996. Ownership dispersion, costly information and IPO underpricing, Journal of Financial Economics, 41, 291-310.

8. Brennen, Michael and Julian Franks, 1995. Underpricing, ownership and control in initial public equity securities in the U.K., Working paper (London Business School, London).

9. Datar, Vinay and David Mao, 1997. Initial Public Offerings in China: Why is underpricing so severe?, Mimeo (Seattle University).

10. Drake, Philip and Michael Vetsuypens, 1993. IPO underpricing and insurance against legal liability, Financial Managemen, 22 (1), 64-73.

11. Garfinkel, Jon, 1993. IPO underpricing, insider selling and subsequent equity offerings: Is underpricing a signal of quality, Financial Management, 22(1), 74-83.

12. Grinblatt, Mark and Chuan Yang Hwang, 1989. Signaling and the pricing of new issues, Journal of Finance 44, 393-420.

13. Hughes, Patricia and Anjan Thakor, 1992. Litigation risk, intermediation and the underpricing of initial public offerings, Review of Financial Studies, 5 (4), 709-742.

14. Ibbotson, Roger, 1975. Price performance of common stock new issues, Journal of Financial Economics 3, 235-272.

15. _ _ _ and Jeffrey Jaffe, 1975. "Hot Issue" markets, Journal of Finance, 30, 1027-1042.

16. J Jody Sindelar, and Jay Ritter, 1988. Initial public offerings, Journal of Applied Corporate Finance $1,37-45$.

17. _ and Jay Ritter, 1993. Initial public offerings in Robert Jarrow, Vojislav Maksimovic, and William Ziemba, eds., Handbooks of operations research and management science: Finance (North-Holland, Amesterdam).

18. Jain, Bharat, and Omesh Kini, 1994. The post-issue operating performance of IPO firms, Journal of Finance 49 (5), 1699-1726.

19. Keloharju, Matti, 1993. The winner's curse, legal liability, and the long-run price performance of initial public offerings in Finland, Journal Financial Economics 34, 251-277.

20. Koh, Francis and Terry Walter, 1989. A direct test of Rock's model of the pricing of unseasoned issues, Journal of Financial Economics, 23, 251-272.

21. Levis, Mario, 1990. The winner's curse problem, interest costs and the underpricing of initial public offerings, Economic Journal, 100, 76-89.

22. Leland, Hayne and David Pyle, 1977. Informational asymmetries, financial structure, and financial intermediation, Journal of Finance, 32 (2), 371-387.

23. Logue, Dennis, 1973. On the pricing of unseasoned equity issues: 1965-1969, Journal of Financial and Quantitative Analysis, 8, 91-103. 
24. Loughran, Tim, Jay Ritter, and Kristian Rydqvist, 1994. Initial public offerings: International insights, Pacific Basin Finance Journal, 2, 165-199.

25. Perotti, Enrico, 1995. Credible privatization, American Economic Review, 85 (4), 847-859.

26. _ and Serhat Guney, 1993. The structure of privatization plans, Financial Management, 22 (1), 84-98.

27. Ritter, Jay, 1984. The hot issue market of 1980, Journal of Business, 57 (2), 215-240.

28. _ 1987. The costs of going public, Journal of Financial Economics, 19, 269-282.

29. 1991. The long-run performance of initial public offerings, Journal of Finance, 46 (1), 3-28.

30. Rudd, Judith, 1993. Underwriter price support and the IPO underpricing puzzle, Journal of Financial Economics, 34, 135-151.

31. Rock, Kevin, 1986. Why new issues are underpriced?, Journal of Financial Economics, 15, 187-212.

32. Sherman, Ann, 1992. The pricing of best efforts new issues, Journal of Finance, 47 (2), 781-790.

33. Smith, Clifford Jr., 1986. Investment banking and the capital acquisition process, Journal of Financial Economics, 15, 3-29.

34. Tinic, Seha, 1988. Anatomy of initial public offerings of common stock, Journal of Finance, 43, 789-822.

35. Welch, Ivo, 1989. Seasoned offerings, imitation costs, and the underpricing of initial public offerings, Journal of Finance, 44, 421-449.

36. _ 1992. Sequential sales, learning and cascades, Journal of Finance, 47 (2), 695-732.

\section{ENDNOTES}

1. For reviews of U.S. and International IPO underpricing, see Smith (1986), Ibbotson and Ritter (1993), and Loughran, Ritter and Rydqvist (1994).

2. Datar and Mao (1997) examine 226 IPOs for class ' $A$ ' share issues to Chinese nationals, and find that these IPOs were underpriced by $388 \%$ on average, compared to an underpricing of $16 \%$ in the U.S.. Furthermore they find that almost every issue is underpriced.

3. The discrepancy between the mean and median value here cannot be attributed to the presence of an outlier. Four stocks offered first day returns over 25\% (and an additional three offered first day returns over 15\%), whereas only one stock generated losses of over $15 \%$ on the first day. Twelve of the forty issues generated first day returns between $-2 \%$ and $+2 \%$.

4. Barry and Jennings (1993) report that the aftermarket price is a random walk for U.S. data.

5. Since $E\left(R_{1}\right)$ is not equal to zero, we also used as an alternative measure of volatility, $\sigma_{1}=\left|R_{1}-E\left(R_{1}\right)\right|$.

6. Using $\sigma_{1}$ as our measure of volatility, the mean is $10.42 \%$ and the median is $5.93 \%$.

7. Ibbotson, Sindelar and Ritter (1988) examine 8668 IPOs in the U.S. and report average underpricing of $16.4 \%$.

8. It may not be clear cut that these time and industry effects are two seperate effects, since two of the three utility issues occurred in 1996, and two of the four issues in 1996 were utility stocks.

9. See Allen and Fallhaber (1989), Grinblatt and Hwang (1989), Welch (1989), Chemmanur (1993), Leland and Pyle (1977), and Gale and Stiglitz (1989).

10. In this view, the lack of evidence for any relationship between retained ownership and underpricing reported above is actually good news for signaling models in general, since signaling motives have limited relevance in the Chinese context (at individual issue level); it would have been damaging if the implications of signaling models were to bear out in absence of any signaling motives.

11. For example see, Rock (1986), and Beatty and Ritter (1986).

12. See footnote number 5 for a definition of $\sigma_{1}$. Using this measure we obtain a coefficient of 1.29 on $\sigma_{1}(\mathrm{t}$ statistic, 3.89) and an $\mathrm{R}^{2}$ of $26 \%$. 


\section{NOTES}

